\title{
A Comparative Study on Green Building Rating Systems in India in terms of Energy and Water
}

\author{
Yashwanth Pamu ${ }^{1}$ and Kona Mahesh ${ }^{2}$ \\ ${ }^{1}$ Assoc.Professor, CVR College of Engineering/Civil Engg. Department, Hyderabad, India \\ Email: yashwanthpamu@gmail.com \\ ${ }^{2}$ Asst.Professor, CVR College of Engineering/Civil Engg. Department, Hyderabad, India \\ Email: konamahesh012@gmail.com
}

\begin{abstract}
Construction Industry has many adverse effects on the environment. Few non-profit organizations have been educating people about the ill-effects of construction activities to bring awareness among people. This awareness among the general public will mandate the builders to choose alternative materials and methods in construction related activities which have less adverse effects on the environment. In order to achieve this, few organizations have setup standards for various materials and procedures in construction to reduce the load on the environment. Two such organizations in India are Indian Green Buildings Council abbreviated as IGBC and Green Rating for Integrated Habitat Assessment abbreviated as GRIHA . IGBC certifies / ratifies buildings like educational, residential, commercial, etc. Out of several criterion mentioned in their respective manuals, energy and water are the most important criteria. In this paper, an attempt is made to compare the two green building rating systems in India for existing buildings in terms of energy and water.
\end{abstract}

Index Terms: Alternative materials, Environmental load, Rating systems, Energy, Water

\section{INTRODUCTION}

In the present world, there is a dearth for energy. Many investigations are taking place for alternative ways of generating energy. The alternative ways should be environment friendly i.e. in the process of generating energy, the environment and the limited resources should be least affected. Abanda and Byers (2016) have investigated that the buildings utilized $32 \%$ of global energy and responsible for $19 \%$ energy related green house gases [16]. Waidyasekhara, De Silva and Rameezdeen (2013) have stated that at present, construction industry is one of the industries that talk more on sustainable and environmental performance [1]. Organizations in India like IGBC and GRIHA have set some standards, by following which, the burden on the environment can be reduced. Both the ratification systems have published their respective manuals on certification of green schools, green campuses, green homes, etc., for new and existing structures after a thorough research by respective organizations. Similarly different countries have their own rating systems. Vierra (2011) mentioned that there are about 600 rating systems in the world [12]. The following table gives the rating systems followed by different countries.
TABLE I.

RATING SYSTEM OF DIFFERENT COUNTRIES

\begin{tabular}{|l|l|l|}
\hline S.No. & Country & Name of the Ratings System \\
\hline 1 & USA & LEED \\
\hline 2 & UK & BREEAM \\
\hline 3 & SINGAPORE & BCA GREEN MARK \\
\hline 4 & CHINA & GBCI \\
\hline 5 & AUSTRALIA & GREEN STAR - AUS \\
\hline 6 & MALAYSIA & GBI \\
\hline 7 & INDIA & IGBC / GRIHA \\
\hline
\end{tabular}

Marjaba and Chidiac (2016) have stated that the widely used ratification system is BREEAM - Building Research Establishment Environmental Assessment Method because of its flexibility in assessing local codes and its application in international buildings [15]. Bourdeau, Huovila, Lanting and Gilham (1998) have mentioned that due to different ideas of sustainable construction in different countries there are different sustainable practices [14]. Dat Daon et al., (2017) have stated that due to need to report concerns in local conditions of different countries or regions, different rating systems have different weightages [10]. As there are two certification / ratification systems in India, construction industry often gets into dilemma about the usage and execution of the systems.. Out of the several criterions in both the systems, energy and water constitute to almost 50\% of the points. Rebecca (2008) have mentioned that the building valuation systems focus on different areas but most of the systems have water conservation and energy efficiency in common [2]. This paper focuses on the differences in the rating systems in India. It is done in terms of energy and water for existing buildings.

\section{GREEN BUILDING CERTIFICATION}

A green building is the one, which minimizes the negative impacts of construction right from its design stage to its operation and maintenance stage. It also uses the scarce resources like sand, gravel, raw materials, energy and water effectively. Joseph and Tretsiakova-McNally (2010) have stated that the construction industry is accountable for consumption of large portion of raw materials usage, exploiting $25 \%$ of wood harvest [17]. Gupta and Kumar (2010) have mentioned that the building construction industry exploits $40 \%$ of stone, sand and gravel globally [19]. Attom, Abed, Elemam, Nazal and ElMessalami (2016) have highlighted that buildings consume $16 \%$ of water globally [18]. $\mathrm{Yu}$ and $\mathrm{Tu}$ (2011) have stated that those 
buildings which are certified by rating systems are assumed to consume relatively less enegy and water [13]. A green building is also known as sustainable building. Boonstra and Pettersen (2003) have highlighted the necessity of environmental assessment methods. This can respond to environmental issues and define sustainable levels [3]. Fowler and Rauch (2006) have explained that sustainable building rating systems are used to test the performance or expected performance of the whole building. It translates performance assessment into a tool that can be used to compare the building performance or a performance standard [4]. Sev (2009) documented that the environmental valuation tools have become common in recent times and fascinated the stake holders of construction [5]. The cerfication will be done by IGBC and GRIHA in India. There will be certain procedures to be followed for certification process. Green building certification for existing buildings give a scope to reduce water and energy requirements. Buildings should continously monitor the environmental performance of the existing buidings and improve them if required to obtain resource efficient habitats. Both the rating systems have certain mandatory requirements, without meeting these requirements, the buildings are not eligible for certification.

\section{About IGBC \& GRIHA}

IGBC was established by the CII - Confederation of Indian Industry in 2001. It is a research institute, head office located in CII Sohrabj Godrej Green Business Center. IGBC has licensed the LEED green building standard from USGBC. LEED - The Leadership in Energy and Environmental Design is the rating system developed by USGBC - United States Green Building Council (USGBC). It is the organization encouraging sustainability through green buildings. It is a structure for gauging building performance compared to set criteria and customary points of reference. The LEED rating system standards were framed in 2000. It ratifies existing and new buildings. Some examples of LEED certified buildings in India are ABN Amro Bank (Ahmedabad) - LEED Platinum rated, American Embassy School (Delhi) - LEED Gold rated, Anna Centenary building (Chennai) - LEED Gold rated etc.

GRIHA was established by TERI - The Energy and Resource Institute. GRIHA is an abbreviation for Green Rating for Integrated Habitat Assessment. The word GRIHA has originated from Sanskrit language, which means 'Abode'. Buildings communicate with environment in many ways. Buildings consume resources in the form of construction materials, waters, energy, etc. Once the buildings are possessed, they effuse waste directly or indirectly. As an old proverb goes, things which can be measured can be managed. GRIHA tries to measure things like energy consumed, waste generated, adoption of renewable energy to manage, regulate and reduce them to least possible extent. Some examples of GRIHA certified buildings in India are ZED Earth villa (Bangalore), Indra Paryavaran Bhavan (New Delhi), IOCL office (Indore) etc.
Both IGBC and GRIHA are ratification tools which helps the construction industry to reduce the harmful effects of construction on the environment thereby promoting sustainable development.

\section{METHODOLOGY}

The content mentioned in this paper is through survey of published papers and manuals available in the respective websites of GRIHA and IGBC. In this paper, a comparison is made between IGBC and GRIHA rating systems for existing buildings in terms of energy and water criterion. The reason for considering only these two criterions is that they contribute to the majority of points though there are other parameters also to be considered for certification.

\section{Criteria AND Their Weightage}

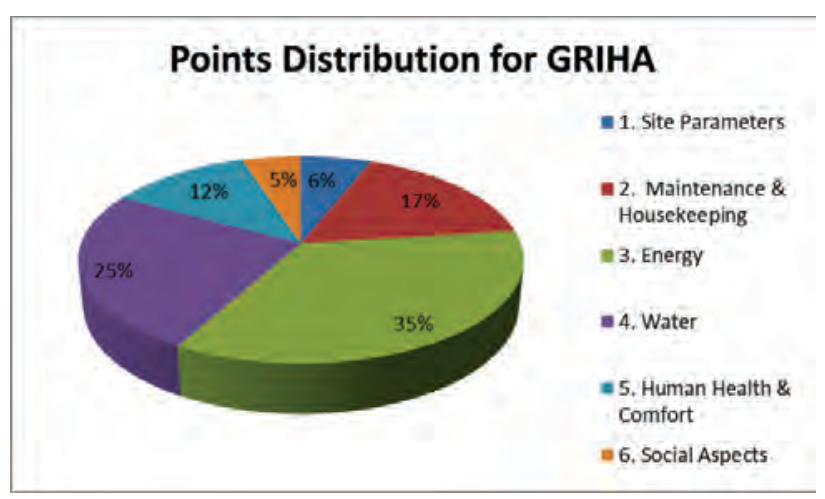

Figure 1. Points Distribution for GRIHA rating system

TABLE II.

LEVELS OF CERTIFICATION BASED ON POINTS EARNED

\begin{tabular}{|l|l|}
\hline \multicolumn{1}{|c|}{ POINTS } & \multicolumn{1}{c|}{ RATING } \\
\hline $25-40$ & ONE STAR \\
\hline $41-55$ & TWO STARS \\
\hline $56-70$ & THREE STARS \\
\hline $71-85$ & FOUE STARS \\
\hline 86 and above & FIVE STARS \\
\hline
\end{tabular}

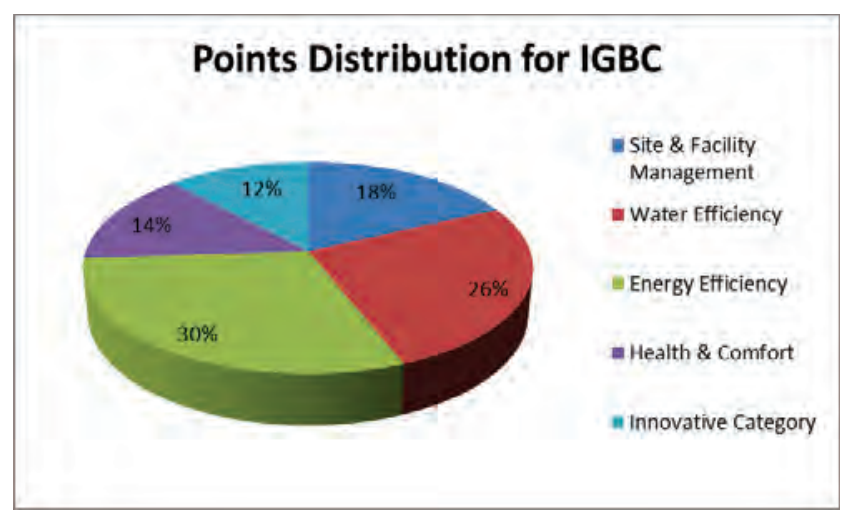

Figure 2. Points Distribution for IGBC rating system 
TABLE III

LEVELS OF CERTIFICATION BASED ON POINTS EARNED

\begin{tabular}{|l|l|}
\hline \multicolumn{1}{|c|}{ POINTS } & \multicolumn{1}{c|}{ RATING } \\
\hline $50-59$ & BEST PRACTICES \\
\hline $60-69$ & $\begin{array}{l}\text { OUTSTANDING } \\
\text { PERFORMANCE }\end{array}$ \\
\hline $70-79$ & $\begin{array}{l}\text { NATIONAL } \\
\text { EXCELLENCE }\end{array}$ \\
\hline $80-100$ & GLOBAL LEADERSHIP \\
\hline
\end{tabular}

GRIHA certification is done for a total of 100 points which excludes bonus 4 points. This bonus points are for adoption and implementation of innovative strategies in improving the sustainability of the project. In GRIHA, the site parameters criteria is given 12 points, maintenance and housekeeping criteria is given 17 points, energy criteria is given 35 points, water criteria is given 25 points, human health and comfort is given 12 points and social aspects criteria is given 5 points. These entire criterions have sub criterions. The validity of ratification for GRIHA certified buildings is five years.

IGBC certification is also done for 100 points which includes 12 points for innovative category. There is no such provision for bonus points as it is done in GRIHA. In IGBC, site facility and management is given 18 points, water efficiency is given 26 points, energy efficiency is given 30 points, health \& comfort is given 14 points and innovative category is given 12 points. The validity of IGBC certified buildings is only three years.

\section{IMPORTANCE OF ENERGY \& WATER CONSERVATION IN SUSTAINABLE DEVELOPMENT}

Buildings contribute to $18 \%$ of total emissions globally which is equal to nine billion tons of carbon dioxide every year. The main aim of a sustainable / green building is to reduce the greenhouse gas emissions and promote energy and water conservation. Building construction involves the use of energy and water directly or indirectly. Generation of energy from non-renewable sources requires consumption of fossil fuels by which greenhouse gases are emitted. These are harmful for the environment. It may have side effects like acid rains. Guggemos and Horvath have (2006) have stated that the construction industry is one of the largest users of energy and water [6]. Fawcet et al., (2012) have stated that the main objective of sustainability is to reduce any damaging upcoming consequences from present usage activities [7]. In green / sustainable buildings, importance is given for energy generation from renewable sources like solar, wind etc. These don't emit greenhouse gases. Though it requires huge initial investment, it is one time investment. The rate of return will be very high. Different rating systems around the world have given different weightage for energy criteria.
Another important aspect of sustainable building is water which includes water conservation and water use efficiency. Water is a limited resource in many countries in the world. The availability of potable water is not sufficient and is decreasing day by day. Waidyasekara

, De Silva and Rameezdeen (2012) highlighted the importance of addressing pollution caused by water because of construction works and the necessity of instigating rules and regulations towards water monitoring and management at construction areas [1]. Water is required right from the beginning of construction to its operation and maintenance phase. David Langdon (2007) reported that scarcity in water means, the cost increases [8]. Reduction in water consumption means reduction in Life Cycle Cost (LCC) of the building. Using good quality water in construction is also important for attaining maximum strength of structures. Utraja (2010), mentioned that the quantity \& quality of water also has a greater effect on the strength of concrete and mortar used in construction work [9]. Different weightage is given by different rating systems for water parameter.

\section{ANALYSIS OF ENERGY PARAMETER IN IGBC \& GRIHA RATING SYSTEMS}

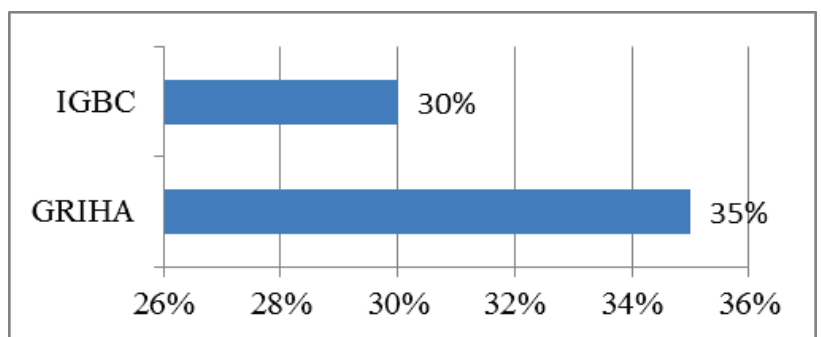

Figure 3. Weightage (\%) for energy criteria for IGBC \& GRIHA

\section{A. Sub criterion in energy for $I G B C$}

TABLE IV

POINTS FOR SUB CRITERION

\begin{tabular}{|c|l|c|}
\hline S.No. & \multicolumn{1}{|c|}{ Sub criteria } & Points \\
\hline 1 & Energy performance & 14 \\
\hline 2 & On-site renewable energy & 6 \\
\hline 3 & Off-site renewable energy & 6 \\
\hline 4 & Energy metering & 4 \\
\hline \multicolumn{2}{|c|}{ TOTAL } & 30 \\
\hline
\end{tabular}

\section{B. Sub criterion in energy for GRIHA}

TABLE V.

POINTS FOR SUB CRITERION

\begin{tabular}{|c|l|c|}
\hline S.No & Sub criteria & Points \\
\hline 1 & Energy efficiency & 20 \\
\hline 2 & Renewable energy utilization & 15 \\
\hline \multicolumn{2}{|c|}{ TOTAL } & 35 \\
\hline
\end{tabular}




\section{ANALYSIS OF WATER PARAMETER IN IGBC \& GRIHA RATING SYSTEMS}

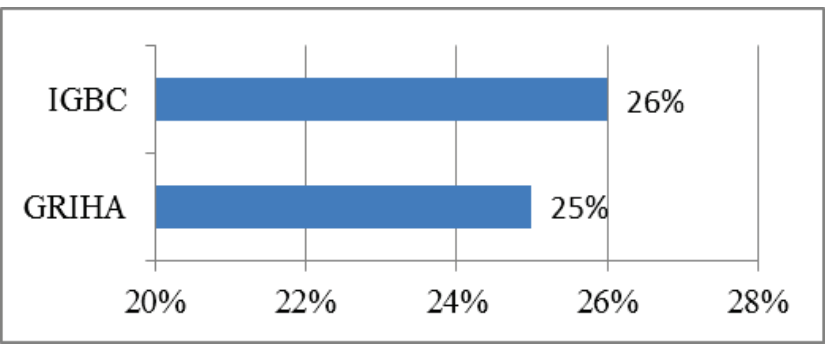

Figure 4. Weightage (\%) for water criteria for IGBC \& GRIHA

\section{A. Sub criterion in water for $I G B C$}

TABLE VI.

POINTS FOR SUB CRITERION

\begin{tabular}{|c|l|c|}
\hline S.No & \multicolumn{1}{|c|}{ Sub criteria } & Points \\
\hline 1 & Water efficient fixtures & 6 \\
\hline 2 & Rain water harvesting & 4 \\
\hline 3 & Waste water treatment & 4 \\
\hline 4 & Waste water reuse & 4 \\
\hline 5 & Water metering & 4 \\
\hline 6 & Turf area & 4 \\
\hline \multicolumn{2}{|c|}{ TOTAL } & 26 \\
\hline
\end{tabular}

\section{B. Sub criterion in water for GRIHA}

TABLE VII

POINTS FOR SUB CRITERION

\begin{tabular}{|c|c|c|}
\hline S.No & Sub criteria & Points \\
\hline 1 & Water footprint & 15 \\
\hline 2 & Reduction in cumulative water & 10 \\
\hline \multicolumn{2}{|c|}{ TOTAL } & 25 \\
\hline
\end{tabular}

\section{Discussions \& CONCLUSIONS}

Construction Industry is one such industry which is responsible for consumption of natural and scarce resources. It is also responsible for global warming. Few organizations have set up some standards. Following these standards, though ill-effects of construction cannot be completely eliminated but can be minimized. Such organizations also certify / ratify buildings based on the methods and materials used right from the beginning of the construction. There are two ratification systems in India namely IGBC and GRIHA. The builder or contractor who would like to go for ratification will be in a state of dilemma on which system they should opt for. In order to avoid this confusion, there should be only one ratification system for a country.

In IGBC, the energy performance sub criteria have a total of 14 points (Table 4 ) whereas GRIHA has 20 points (Table 5). In this sub criteria, IGBC has given two methods to calculate energy savings and it has also given values for different climatic conditions (composite, warm \& humid and hot $\&$ dry temperature) for different types of buildings (day time office building, shopping malls, BPOs). The points are awarded based on the energy savings percentage. In case of GRIHA, there is not much of ambiguity in calculating reduction in energy consumption. Based on the percentage reduction in energy consumption, points are awarded for residential and non-residential / commercial buildings respectively. GRIHA calculations are easy to understand and execute when compared to that of IGBC.

In IGBC, 6 points each are awarded for on-site and offsite renewable energy based on the percentage of on-site and off-site renewable energy production. Similarly, 20 points are given for on-site and off-site renewable energy which is based on the percentage usage of renewable energy. In both the ratings systems the calculations are simple and can be easily understood. Energy metering has allotted 4 points for IGBC. In case of GRIHA 3 points are under different criteria, Metering \& Monitoring. If this can be included in energy criteria section, then all the energy related criteria can be found in a single place.

Comparing the water criteria, total points are 26 and 25 for IGBC and GRIHA respectively, which means equal importance is given for water in both ratification systems. Using water efficient fixtures are a mandatory requirement in IGBC; water efficient fixtures are given 6 points based on the percentage of potable water savings over baseline. The baseline details are mentioned in the IGBC manual, whereas there is no such mandatory requirement in case of GRIHA but reduction in building water consumption by $30 \%$ below the base case through water efficient fixtures is given 3 points. The methodology for calculating water consumption and water use reduction is little complicated but can be simplified to a certain extent. In IGBC, rain water harvested on site from roof and non-roof areas are given 4 points based on the percentage of rain water harvested on site. In places where the state / central ground water board don't recommend artificial rain water recharge or if the groundwater table is less than $4 \mathrm{~m}$, the projects can show nominal compliance by collection and reuse. The points are given based on percentage rainwater harvesting system from roof and non-roof areas. In case of GRIHA, minimizing lawn area and restricting it to $25 \%$ of total landscaped area gives 2 points. Use of water efficient irrigation fixtures to decrease the water requirement by at least $50 \%$ from GRIHA base case (mentioned in the GRIHA manual) gives 2 points. Use of water efficient irrigation fixtures isn't mentioned in the IGBC manual.

If $100 \%$ of waste water is treated on site for reuse of safe disposal to avoid polluting streams, it can fetche 4 points in case of IGBC. Further 4 points are awarded based on the percentage of treated water reuse. Treated water can be used for irrigation or flushing requirements which reduce the dependence on potable water. GRIHA assigns 10 points for this sub criteria depending upon the percentage of reuse of treated water.

IGBC and GRIHA assign 4 points for water metering. IGBC gives 4 points for minimizing the turf area whereas GRIHA gives 2 points based on the percentage reduction. 
By the differences observed, it is always better to have a common system of ratification. The procedure for ratification shouldn't be cumbersome. Another important aspect is that the cost of ratification for both the ratification systems is very high. Government of India should provide good incentives for ratified buildings to encourage sustainable buildings. The incentives provided are very less.

It is also observed that both the rating systems have addressed the benchmarks for energy and water for buildings during the operation \& maintenance stage, but the limits for activities during the construction period have not been mentioned. With the fast moving pace of technology, a need for automation has arisen. For efficient energy management, automation is necessary, but nothing is mentioned in both the rating systems regarding automation. It is therefore recommended to include automation related parameters in the rating systems.

After the building gets certified, there should be periodical inspections during the certification period from the certification agencies to monitor the maintenance of the building. This should be done to avoid the misuse of the certification. Due to the increased awareness of the sustainable buildings, few builders may rent / lease / sell the certified buildings to a higher price.

\section{REFERENCES}

[1] Waidyasekara., K.G.A.S, De Silva., M.L, and Rameezdeen, R. (2013). "Comparative Study of Green Building Rating Systems: In terms of Water Efficiency and Conservation". The Second World Construction Symposium 2013: SocioEconomic Sustainability in Construction, 14-15 June 2013, Colombo, Sri Lanka, pp. 108-117

[2] Rebecca., C. Retzlaff. (2008). "Green building assessment systems - A framework and comparison for planners". Journal of American Planning Association, pp. 505-519

[3] Boonstra., C. and Petterson, T.D. (2003) "Tools for environmental assessment of existing buildings" (online) Sustainable Building and Construction", UNEP Industry and Environment, April 2003

[4] Fowler., K.M and Rauch, E.M.(2006). "Sustainable building rating systems-summary", The pacific north west national laboratory, operated for the U.S. department of energy by battelle, PNNL -15858, 2006.

[5] Sev, A. (2009) "A comparative analysis of building environmental assessment tools and suggestions for regional adaptations". Civil Engineering and Environmental Systems, Vol. 28, No. 3, September 2011, pp. 231-235.

[6] Guggemos., A.A. and Horvath, A. (2006). "Decision support tool for assessing the environmental effects of constructing commercial buildings", Journal of Architectural Engineering, 2006, pp. 187-195.

[7] Fawcet., W, Hughes., M, Krueg., H, Albrecht., S, and Vennstro, A. "Flexible strategies for long term sustainability", Building Research and Information, 2012, pp. 545-557

[8] Davis Langdon. (2007). "The cost and benefits of green buildings, innovative thinking in property and construction" (online).
[9] Utraja, G. (2010) “Water for construction (online) available form: www.gharexpert.com/articles/water-1837

[10] Dat Doan, Ali Ghaffarianhoseini, Nicola Naismith and Tongrui Zhang. (2017) "A critical comparision of green building rating systems". Building and Environment, pp. 1-26.

[11] Waidyasekara., K.G.A.S, De silva., M.L, and Rameezdeen, R. (2012) Value of sustainable use of water in construction industry, $2^{\text {nd }}$ International Conference on Sustainable Built Environment, 14-16 December 2012 at Kandy, Sri Lanka.

[12] Viera, S.(2011). "Green building standards and certification systems". Washington DC: Steve Winter Associates.

[13] Yu., S.M., Tu, Y. (2011). "Are green buildings worth more because they cost more." NUS Institute of Real Estate Studies working paper (IRES 2011-023).

[14] Bourdeau., L, Huovila., P, Lanting., R, and Gilham, A. (1998). "Sustainable development and future of construction A comparision of visions from various countries." Journal on Building Research and Information.

[15] Marjaba., G. and Chidiac, S. (2016). "Sustainability and resiliency metrics for buildings - critical review." Building and Environment 101., 10.1016/j.buildenv.2016.03.002.

[16] Abanda., F and Byers, L. (2016). "An investigation of the impact of the building orientation on energy consumption in a domestic building using emerging Building Information Modeling (BIM).” Energy 97., 10.1016/j.energy.2015.12.135

[17] Joseph., P and Tretsiakova-McNally, S. (2010). "Sustainable non-metallic building materials." Sustainability 2., $10.3390 /$ su2020400.

[18] Attom., M, Abed., F, Elemam., M, Nazal., M, and ElMessalami, N. (2016). "The effect of treated waste water on compaction and compression of fine soil" World Academy of Science, Engineering and Technology, International Journal of Civil, Environmental, Structural, Construction and Architectural Engineering.

[19] Gupta, A., and Kumar, A. (2010). "Composite materials: addressing the climate change." Asia Pacific Business review., 10.1177/097324701000600107

[20] Indian Green Buildings Council (IGBC) - Green existing buildings operation and maintenance abridged reference guide, April 2013.

[21] Green Rating for Integrated Habitat Assessment (GRIHA) for existing buildings, 2017. 